\title{
Utilization of tekelan leaf extract (Chromolaena odorata L.) based on nanoliposome technology as treatment of antihyperglycemia
}

\author{
Sofia Rahmi $^{1}{ }^{*}$, Rosidah ${ }^{1}$, Tri Widyawati ${ }^{1}$, and Sumaiyah ${ }^{1}$ \\ ${ }^{1}$ Department Pharmacology, Faculty of Pharmacy, Universitas Sumatera Utara, Jl. Tri Dharma no 5, \\ Medan, 20155, North Sumatera, Indonesia.
}

\begin{abstract}
Metabolic disease that occurs due to abnormalities in insulin secretion and insulin action is said to be diabetes or hyperglycemia. One alternative that can be used for hyperglycemia management is to use tekelan leaves $(C$. odorata $\mathrm{L}$.). The leaves of this tekelan plant have low water solubility and high permeability. A liposome is a good carrier to increase the solubility and penetration of the compounds it carries. This study aimed to develop a nanotechnological liposomal preparation from the ethanol extract of tekelan leaves as a hypoglycemic agent in diabetic male rats induced by nicotinamide $120 \mathrm{mg} / \mathrm{kg} \mathrm{BW}$ and streptozotocin 60 $\mathrm{mg} / \mathrm{kg} \mathrm{BW}$. Antihyperglycemia treatment was applied to nanoliposomes at a dose of $25 \mathrm{mg} / \mathrm{kg} \mathrm{BW}, 125 \mathrm{mg} / \mathrm{kg} \mathrm{BW}, 250 \mathrm{mg} / \mathrm{kg} \mathrm{BW}$, CMC-Na and $0.45 \mathrm{mg} / \mathrm{kg} \mathrm{BW}$ of glibenclamide. The results obtained were at 12 'sonication time, the resulting particle size is $145.5 \pm 2.8$ and PI $0.307 \pm$ 0.03 . The results of antihyperglycemia testing were obtained at a nanoliposome dose of $250 \mathrm{mg} / \mathrm{kg}$ BW produced the lowest blood glucose levels, namely, $86 \pm 4.30 \mathrm{mg} / \mathrm{dL}$.
\end{abstract}

\section{Introduction}

Metabolic disease that occurs due to abnormalities in insulin secretion and insulin action is said to be diabetes or hyperglycemia. In the world, about 425 million people have diabetes. The number will increase to 600 million people estimated by 2040 [ 1].

Hyperglycemia medication consumption often causes side effects. Research is often conducted to find drugs that are more effective and safer [2]. A traditional plant that can be used as alternative medicine is the leaves of tekelan ( $C$. odorata L.). There are active compounds in tekelan leaves, namely flavonol 3'4'-dihydroxiflavone (quercetin), which has antioxidant, antiproliferative, anti-inflammatory, anti-diabetic, anti-carcinogenic, antihypertensive, antidiabetic, and protects against various types of diseases such as osteoporosis, certain forms of cancer, lungs, and heart, also against aging [3].

\footnotetext{
*Corresponding author: rahmisofia10@gmail.com
} 
The body can be protected from several types of degenerative diseases by preventing the occurrence of lipid peroxidation in the presence of quercetin [4]. However, quercetin has a weakness in terms of water solubility and high permeability. For that, we need technology to increase bioavailability so that the maximum therapeutic effect is obtained.

There is one type of drug delivery that is currently being developed. These types are liposomes. With the presence of liposomes, solubility can be increased, and the penetration of compounds in the patient's body can grow. Liposomes are formed from the interaction between hydrophilic-hydrophobic compounds or between phospholipids and water molecules [5].

The novelty of this research is the development of a liposome nanotechnology preparation of tekelan leaf ethanol extract as an antidiabetic which was tested on white male rats.

\section{Research method}

\section{1 Research tools}

The tools used in this study were glass tools (stirring rod, watch glass, glass beaker, measuring cup, turtle spoon). 500-1000 $\mu \mathrm{L}$ micropipette, analytical scale (Metler Toledo), rotary evaporator (Heidolph), Transmission Electron Microscopy (JEM 1400, JEOL), Particle Size and Zeta potential (Horiba SZ 100), pH meter (Horiba), cabinet dryer, furnace (thermolyne, thermos scientific), pycnometer (pyrex), atomic absorption spectrophotometry (PerkinFlmer, PnAAcle 900T), oven (Memmert), glucose stick (Aqu-Check), animal scales.

\subsection{Research materials}

The materials used in this study were tekelan leaves obtained from Deli Tua (North Sumatra), aquabidestilata (Ikapharmindo), nicotinamide (Sigma Aldrich), streptozotocin (Sigma Aldrich), Lipoid S75, Lipoid DMPG-Na, cholesterol (Sigma Aldrich), span-60, blue tip, microtubes, glucose (Sigma Aldrich), glibenclamide, $\mathrm{NaCl}$ (Sigma Aldrich), methanol (Merck), chloroform (Merck), and PBS (Phosphate Buffer Saline) (Merck).

\subsection{Research stage}

\subsubsection{Preparation of tekelan leaf ethanol extract}

Tekelan leaf powder obtained from refining tekelan leaves from the Deli Tua region, North Sumatra, was extracted using $1.5 \mathrm{~L}$ ethanol $96 \%$ by maceration method. After obtaining the liquid extract, it is concentrated with a rotary evaporator at a temperature of $50^{\circ} \mathrm{C}$ until a thick extract is obtained [6].

\subsubsection{Phytochemical screening}

Phytochemical screening was carried out to identify what metabolites are present in tekelan leaves. The phytochemical screening identified alkaloid compounds, flavonoids, tannins, steroids / triterpenoids, and glycosides [3]. 


\subsection{Preparation of Liposome Extract Nanotechnology for Tekelan Leaves}

The liposomes of the tekelan leaf ethanol extract were prepared using a thin layer hydration method. The liposome material was made in two mixtures, namely Mix A (consisting of S75 lipoids, DMPG-Na lipoids, cholesterol, and span 60). Mixture B (consisting of methanol, chloroform, ethanol extract of tekelan leaves). The two ingredients are put into a round appliance flask, then evaporated by a rotary evaporator and heated to a temperature of $60^{\circ} \mathrm{C}$ with a pressure of $200 \mathrm{mBar}$ for 1 hour. This was done until a thin layer was formed on the walls of the round bottom flask, then PBS was added into the flask. The niosome results were taken. Furthermore, it was purified with a PD 10 column, collected into a container; then downsizing was carried out using ultrasonic with sonication times of 2 seconds, 4 seconds, 6 seconds, 8 seconds, 10 seconds, and 12 seconds. Analysis with a particle size analyzer (PSA). Liposome formulations can be seen in Table 1 below.

Table 1. Formulation of Tekelan leaf liposomes

\begin{tabular}{|l|c|}
\hline \multicolumn{1}{|c|}{ Ingredient Name } & Formulations \\
\hline Ethanol extract of tekelan leaves & $100 \mathrm{mg}$ \\
\hline Lipoid S75 & $95 \%$ \\
\hline Lipoid DMPG-Na & $5 \%$ \\
\hline Cholesterol & $5 \%$ \\
\hline Methanol & $5 \mathrm{~mL}$ \\
\hline Chloroform & $5 \mathrm{~mL}$ \\
\hline PBS saline & $10 \mathrm{~mL}$ \\
\hline
\end{tabular}

\subsubsection{Liposome morphology test}

The morphological characteristics and size of the liposomes were evaluated by TEM (Transmission Electron Microscopy). Liposome samples were diluted with 20x and 50x dilutions, then one drop was dropped on a formvar coated cumprum grid and dried at room temperature; after drying, samples were analyzed by TEM. The samples were put in a container and analyzed at $25^{\circ} \mathrm{C}$ [7].

\subsubsection{Particle Size observation and polydispersion index}

The particle size measurement and polydispersion index was carried out using a particle size analyzer (Horiba SZ 100), the sample was inserted into the cuvette after 100x dilution. The stability of the liposome preparations was evaluated organoleptically in the form of color changes and the formation of particulates that were dispersed into the PBS carrier liquid [8].

\subsection{Production of hyperglycemia in rats}

The mice were adapted for one week before being treated. After one week of adaptation, the mice were induced using nicotinamide $120 \mathrm{mg} / \mathrm{kg} \mathrm{BW} .15$ minutes later, followed by streptozotocin induction at a dose of $60 \mathrm{mg} / \mathrm{kg} \mathrm{BW}$. The inducer is given intraperitoneal to cause type-2 diabetes mellitus. If there is an increase in rat blood glucose levels to \pm 200 $\mathrm{mg} / \mathrm{dL}$, the rats are considered to have hyperglycemia [9]. 


\subsubsection{Antihyperglycemia Test in Male White Rats}

Tekelan leaf niosome antihyperglycemia test was given with a variety of doses, namely $25 \mathrm{mg} / \mathrm{kg} \mathrm{BW}, 125 \mathrm{mg} / \mathrm{kg} \mathrm{BW}$, and $250 \mathrm{mg} / \mathrm{kg} \mathrm{BW}$, which was given orally once per day CMC-Na was used as a negative control, and glibenclamide $0.45 \mathrm{mg} / \mathrm{kg} \mathrm{BW}$ was used as a positive control. The five groups were measured for their blood glucose levels on day 0.3 , $6,9,12$, and 15 . Normal glycemia levels are $75-150 \mathrm{mg} / \mathrm{dL}$, mild glycemia $150-200 \mathrm{mg} / \mathrm{dL}$ moderate $200-400 \mathrm{mg} / \mathrm{dL}$ and severe glycemia conditions above $400 \mathrm{mg} / \mathrm{dL}$ [10].

\section{Results and discussion}

\subsection{Results of phytochemical screening}

The results of the phytochemical screening of tekelan leaves can be seen in Table 2 below.

Table 2. Phytochemical screening results

\begin{tabular}{|l|c|c|}
\hline \multicolumn{2}{|c|}{ Results of Tekelan Leaf Phytochemical Screening } \\
\hline Compound & Powder & Extract \\
\hline Alkaloids & + & + \\
\hline Flavonoids & + & + \\
\hline Tannins & + & + \\
\hline Saponins & + & + \\
\hline Steroids/triterpenoids & + & + \\
\hline Glycosides & + & + \\
\hline
\end{tabular}

Based on Table 2, the results of phytochemical screening of powders and extracts produced secondary metabolites in the form of alkaloids, flavonoids, tannins, saponins, steroids/triterpenoids, and glycosides. This is in accordance with Marianne's research [6] which states that the ethanolic extract of tekelan leaves contains secondary metabolites of alkaloids, flavonoids, tannins, saponins, steroids/triterpenoids, and glycosides.

\subsection{Results of liposome nanotechnology formulation, characterization, and physical stability}

\subsubsection{Organoleptic results}

The organoleptic results observed were the distinctive odor of tekelan leaves, brownishgreen color, and a cloudy consistency such as suspension.

\subsubsection{TEM (Transmission Electron Microscopy) observation}

Liposome nanotechnology TEM observations can be seen in Fig. 1 below. 

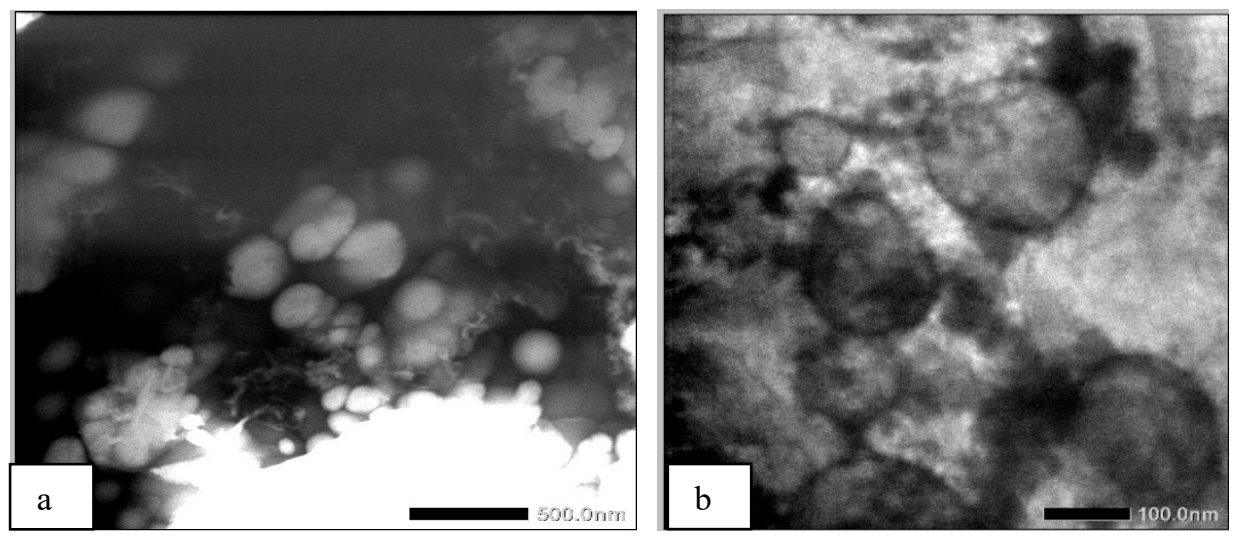

Fig. 1. TEM Results at 10,000 Times Magnification of Niosome Ethanol Extract Leaf Tekelan (C. odorata L.) Formulation-3 with Sonication Time 30 minutes. (a) before purification, image (b) after purification

The TEM (Transmission Electron Microscope) results from the liposomes of the tekelan leaf extract were somewhat rounded with different particle sizes before and after purification. Before undergoing purification, the TEM size of the liposomes of the tekelan leaf extract was $500 \mathrm{~nm}$, and after undergoing purification, the TEM size was $100 \mathrm{~nm}$.

Abinav et al. [10] stated that the size of the vesicle diameter is influenced by the amount of cholesterol, the solvent, and the surfactants that form it. [11] stated that the particle size after purification showed smaller results compared to that before purification. This indicates that purification has resulted in pure nanoparticles. The purification process was carried out to determine the percentage of the ethanol extract of tekelan leaves that could be absorbed in the resulting niosome vesicles. The absorption process can form better bilayer vesicles [12].

\subsubsection{Results of observation of particle size and polydispersion index}

The results of observing the particle size and polydispersion index can be observed in Table 3 below.

Table 3. Observation results of particle size and Liposome Polydispersion Index Tekelan leaf ethanol extract

\begin{tabular}{|c|c|c|}
\hline \multirow{2}{*}{ Sonication Time (minutes) } & Particle Size $(\mathrm{nm} \pm \mathrm{SD})$ & PI $(\mathrm{D} \pm \mathrm{SD})$ \\
& & \\
\hline 2 & $286,5 \pm 8,3$ & $0,419 \pm 0,06$ \\
\hline 4 & $194,7 \pm 1,6$ & $0,530 \pm 0,04$ \\
\hline 6 & $186,5 \pm 2,8$ & $0,376 \pm 0,09$ \\
\hline 8 & $175,9 \pm 3,9$ & $0,359 \pm 0,07$ \\
\hline 10 & $162,6 \pm 5,5$ & $0,345 \pm 0,04$ \\
\hline 12 & $145,5 \pm 2,8$ & $0,307 \pm 0,03$ \\
\hline
\end{tabular}

The ethanol extract of the tekelan leaves used for the manufacture of liposomes was $10 \%$. A good liposome particle size is $100 \mathrm{~nm}-150 \mathrm{~nm}$, while a good PI (Polidispersity Index) is $<0.7 \mathrm{D}, \mathrm{PI}$ is tested to determine the homogeneity of the solution, the smaller the PI, the better the homogeneity. 
The sonication time of 12 minutes had the smallest particle size, namely $145.5 \pm 2.8$ and PI $0.307 \pm 0.03$. The longer the sonication time will cause the liposome temperature to increase. This is because the energy used to reduce the size of the vesicles changes shape to heat. At one time, the vesicle size will reach the smallest (optimum) size, in this condition, the vesicle is relatively more stable [13].

Particle distribution is one of the important factors that need to be considered in the characteristics of liposomes. The good particle distribution indicates the ability of the preparation to get better at loading and releasing the drug to achieve the expected therapeutic effect. The longer the sonication time is carried out in making liposomes, the better the evenness of the particle distribution in terms of particle size, particle distribution graphs [14].

\subsection{Results of Measurement of Average Blood Glucose Levels Before and After Induction of}

\section{3. 1 Nicotinamide and Streptozotocin}

Measurement of average blood glucose levels before and after nicotinamide and streptozocin induction can be seen in Table 4 below.

Table 4. Average KGD measurement results before and after Induction Nicotinamide and Streptozotocin $(\mathrm{mg} / \mathrm{dL})$

\begin{tabular}{|l|c|c|}
\hline \multicolumn{1}{|c|}{ Treatment } & $\begin{array}{c}\text { Mean fasting KGD } \pm \\
\text { SD }(\mathrm{mg} / \mathrm{dL})\end{array}$ & $\begin{array}{c}\text { Mean KGD After Induction of } \\
\text { Streptozotocin and Nicotinamide } \pm \\
\text { SD } \\
(\mathrm{mg} / \mathrm{dL})\end{array}$ \\
\hline Na-CMC & $83,2 \pm 2,95$ & $234,6 \pm 8,85$ \\
\hline Glibenklamide $0,45 \mathrm{mg} / \mathrm{kg} \mathrm{BW}$ & $83,6 \pm 2,30$ & $370,6 \pm 18,68$ \\
\hline Liposome extract $25 \mathrm{mg} / \mathrm{kg} \mathrm{BW}$ & $83 \pm 2,24$ & $286,6 \pm 10,85$ \\
\hline Liposome extract $125 \mathrm{mg} / \mathrm{kg} \mathrm{BW}$ & $83,2 \pm 2,17$ & $372,8 \pm 12,70$ \\
\hline Liposome extract $250 \mathrm{mg} / \mathrm{kg} \mathrm{BW}$ & $87,4 \pm 1,14$ & $367,6 \pm 13,90$ \\
\hline
\end{tabular}

Measurement of blood glucose levels for each treatment day $0,3,6,9,12$, and 15 can be seen in Table 5 below. 
Table 5. Measurement of blood glucose levels for each treatment $(\mathrm{mg} / \mathrm{dL})$

\begin{tabular}{|l|c|c|c|c|c|c|}
\hline Treatment & Day-0 & Day -3 & Day -6 & Day -9 & Day -12 & Day 15 \\
\hline CMC-Na & 234,6 & 234,6 & 232,8 & $231^{\mathrm{b}}$ & 229 & $226,2^{\mathrm{b}}$ \\
& \pm & \pm & \pm & \pm & \pm & \pm \\
& 8,85 & 8,85 & 8,75 & 9,43 & 9,43 & 8,98 \\
\hline Glibenklamide & 370,6 & 344,2 & 324,4 & $220^{\mathrm{a}}$ & $166,6^{\mathrm{b}}$ & $110^{\mathrm{a}}$ \\
$0,45 \mathrm{mg} / \mathrm{kg} \mathrm{BW}$ & \pm & \pm & \pm & \pm & \pm & \pm \\
& 18,68 & 6,38 & 16,64 & 31,18 & 15,47 & 9,30 \\
\hline \multirow{2}{*}{ Liposome extract } & 375,4 & 325,4 & 274 & $230,6^{\mathrm{a}}$ & 171,2 & $126,4^{\mathrm{b}}$ \\
$25 \mathrm{mg} / \mathrm{kg} \mathrm{BW}$ & \pm & \pm & \pm & \pm & \pm & \pm \\
& 10,14 & 9,18 & 8,72 & 5,50 & 8,47 & 8,73 \\
\hline \multirow{2}{*}{ Liposome extract } & 372,8 & 280,4 & 271,8 & $230,6^{\mathrm{a}}$ & $168^{\mathrm{b}}$ & $116,2^{\mathrm{a}}$ \\
125 mg / kg BW & \pm & \pm & \pm & \pm & \pm & \pm \\
& 12,70 & 15,47 & 11,78 & 11,41 & 15,48 & 12,46 \\
\hline \multirow{2}{*}{ Liposome extract } & 286,6 & 235 & 160,2 & $121,8^{\mathrm{a}}$ & $112,4^{\mathrm{b}}$ & $86^{\mathrm{a}}$ \\
$250 \mathrm{mg} / \mathrm{kg} \mathrm{BW}$ & \pm & \pm & \pm & \pm & \pm & \pm \\
& 10,85 & 5,96 & 4,38 & 1,79 & 5,64 & 4,30 \\
\hline
\end{tabular}

Information :

$\mathrm{a}=$ not significantly different from glibenclamide

$\mathrm{b}=$ not significantly different from CMC-Na

The results of measuring blood glucose levels showed that the liposome nanotechnology extract of ethanol leaves of tekelan leaves with a dose of $250 \mathrm{mg} / \mathrm{kg} \mathrm{BW}$ had the lowest value in reducing glucose levels in mice, namely $86 \pm 4.30 \mathrm{mg} / \mathrm{kg} \mathrm{BW}$. And based on the results of statistical observations, it can be seen that the liposomes of ethanol extract of leaves of tekelan at doses of $25 \mathrm{mg} / \mathrm{kg} \mathrm{BW}, 125 \mathrm{mg} / \mathrm{kg} \mathrm{BW}$, and $250 \mathrm{mg} / \mathrm{kg} \mathrm{BW}$ of body weight are not significantly different from glibenclamide doses of $0.45 \mathrm{mg} / \mathrm{kg} \mathrm{BW}$ in terms of reducing blood glucose levels in rats-white male. However, the three liposome nanotechnology have significant differences with $\mathrm{CMC}-\mathrm{Na}$ in terms of lowering blood glucose levels.

\section{Conclusions}

This study concluded that the liposome nanotechnology formulation obtained the smallest particle size in the 12th minute with a particle size of $145.5 \pm 2.8 \mathrm{~nm}$ and a polydispersion index of $0.307 \pm 0.03$. Based on the smallest particle size formulation, when tested as an antihyperglycemia with various doses, a nanoliposome dose of $250 \mathrm{mg} / \mathrm{kg} \mathrm{BW}$ resulted in the lowest blood glucose levels of $86 \pm 4.30 \mathrm{mg} / \mathrm{dL}$.

This research was achieved in collaboration with the Integrated Pharmacy Laboratory of the Islamic University of Indonesia and The Universitas Sumatera Utara. The researcher would like to thank both laboratories for helping to complete this research.

\section{References}

1. L. S. Fatimah, Indonesian Journal of Pharmacy, 27(2), 74-82, (2016).

2. G. Brachmachari, Scientia Jurnal Farmasi Kesehatan, 7(2), 77-89, (2011).

3. M. Fitrah, W. Hendig, and S. Partomuan, Indonesian Journal of Pharmaceutical Sciences. ISSN. 1693-1831, 1115(1), 78-85. (2017). 
4. Z. Bakova, and J. Kolesarova, Microbial Biotechn and FoodSci, 2(12), 106-112, (2012).

5. K. Shashi, K. Satinder, and P. Bharat, International Research Journal of Pharmacy, 3(2), 234-240, (2012)

6. Marianne, D. Lestari, E. Y. Sukandar, N. F. Kurniati, and R. Nasution, Natural Journal, 14(1), 4-10, (2014)

7. B. H. Nugroho, A. D. K. Ningrum, D. A. Pertiwi, T. Salsabila, and Y. Syukri, Jurnal Ilmu-Ilmu MIPA, 19(2), 219-228, (2019).

8. N. E. Fitriani, S. A. Akhmad, and W. Lestariana, JKKI, 6(2): 107-115, (2014)

9. N. T. Saputra, I. S. Nyoman, and A. G. Anak, Udayana Veterinary Bulletin, 10(2), 118-119, (2018).

10. K. Abhinav, P. J. Lal, J. Amit, and S. Vishwabhan, International Research Journal of Pharmacy, 2, 34-45, (2011).

11. D. Y. Pertiwi, S. Djajadisastra, A. Mutalib, and A. Pujianto, Jurnal Ilmu Kefarmasian Indonesia, 16(1), 4-12, (2018).

12. A. Fatmawaty, Subhan., and Muliawati. Journal of Pharmaceutical and Medical Science, 2(4), 6-12, (2016).

13. B. Delfiana, and Astuti. Journal of Physics Unand, 2(3), 186-193, (2013).

14. M. Abdassah, Farmaka, 15(1), 45-52, (2015). 